\title{
Consequences of intraoperative spinal cord manipulation in dogs with thoracolumbar intervertebral disc extrusion
}

\author{
[Consequências da manipulação medular intraoperatória em cães com extrusão intervertebral \\ de disco toracolombar] \\ C.C. Diogo ${ }^{1}$, E.A. Tudury ${ }^{1}$, M.A. Bonelli, B.M. Araújo ${ }^{1}$, M.L. de Figueiredo ${ }^{1}$, T.H.T. Fernandes ${ }^{1}$, \\ A.C. Silva ${ }^{1}$, D. Baraúna Júnior ${ }^{1}$, C.R.O. Santos ${ }^{1}$, M.M.A. Amorim ${ }^{1}$, M.V. Bahr Arias ${ }^{2}$ \\ ${ }^{1}$ Universidade Federal Rural de Pernambuco - Recife, PE \\ ${ }^{2}$ Universidade Estadual de Londrina - Londrina, PR
}

\begin{abstract}
The objective of the present study was to evaluate if extradural contact during hemilaminectomy would cause neurological deterioration in the early and/or late postoperative period in dogs with intervertebral disc extrusion. Nineteen dogs with thoracolumbar intervertebral disc extrusion underwent hemilaminectomy for spinal cord decompression and removal of extruded disc material. Meningeal contacts during surgery were quantified. Paraplegia (with nociception) and paraparesis were observed in $11 / 19$ and 8/19 of dogs, respectively, before surgery. At the end of our study, only two (2/19) had paraplegia and one (1/19), paraparesis. There were more extradural contacts when extruded intervertebral disc material was at a ventrolateral position. Extradural contacts during surgery had no influence on neurological progression nor on time to recovery of motor function. Immediately ( 24 and 48 hours) after surgery, 13/19 dogs had the same neurological stage before surgery. At 7 and 90 days, 13/19 and 17/19 dogs, respectively, showed neurological improvement, compared with their preoperative stage. There was no influence of the number of extradural contacts on neurological recovery. These findings indicate that a careful inspection of the vertebral canal for removal of as much extruded disc material as possible does not cause neurologic deterioration.
\end{abstract}

Keywords: canine, disc herniation, hemilaminectomy, spinal cord

\section{RESUMO}

O presente trabalho teve como objetivo avaliar se contatos extradurais durante hemilaminectomia em cães com extrusão de disco intervertebral causariam piora neurológica no pós-operatório imadiato elou tardio. Dezenove cães com extrusão toracolombar de disco intervertebral foram submetidos à hemilaminectomia para descompressão medular e remoção do material extruso. Durante o procedimento cirúrgico, os contatos meningomedulares foram quantificados. Antes da cirurgia, 11/19 cães apresentavam paraplegia (com nocicepção) e 8/19 cães, paraparesia. Ao fim do estudo, apenas dois cães (2/19) mostravam paraplegia com dor profunda e um (1/19), paraparesia. Observou-se maior quantidade de contatos extradurais quando o material discal extruso encontrava-se em posição ventrolateral. Os contatos extradurais não mostraram influência estatística na evolução neurológica dos animais, bem como no tempo de recuperação das funções motora. Vinte e quatro e 48 horas após a cirurgia, 13/19 cães apresentavam o mesmo grau neurológico de antes da cirurgia. Após sete e 90 dias de pósoperatório, 13/19 e 17/19 demonstraram melhora neurológica em comparação com o pré-operatório, respectivamente. A quantidade de contatos extradurais não influenciou na recuperação neurológica dos cães. Esses achados indicam que uma inspeção minuciosa do canal vertebral pode ser recomendada, a fim de remover o máximo de material discal extruso, evitando-se piora neurológica por compressão medular.

Palavras-chave: canino, hérnia de disco, hemilaminectomia, medula espinal

Recebido em 14 de outubro de 2016

Aceito em 11 de fevereiro de 2017

E-mail: camila_diogo@hotmail.com 


\section{INTRODUCTION}

Thoracolumbar intervertebral disc disease (IVDD) can result from a total rupture of the annulus fibrosus and extrusion of nucleus pulposus (Hansen type I) or protrusion of annulus fibrosus caused by a partial rupture of the annulus, called Hansen type II (Hansen, 1952). Intervertebral disc (IVD) extrusion or IVDD type I is an important cause of spinal cord injury in dogs (Noussitou et al., 2015). It can occur in different breeds, especially chondrodystrophic breeds (Kranenburg et al., 2013; Smolders et al., 2013; Rosenblatt et al., 2015).

Although there are several surgical techniques for decompression of the thoracolumbar spinal cord in intervertebral disc disease, hemilaminectomy is the most often performed (Laitinen and Puerto, 2005; Bush et al., 2007; Kunz et al., 2015; Rohner et al., 2015). The goal of the surgery is to obtain access to the vertebral canal for removal of the disc material with minimal spinal cord manipulation, thus avoiding postoperative neurological deterioration (Sharp and Wheller, 2005).

Disc material that is difficult to remove can result in contact with and manipulation of the spinal cord, which may cause iatrogenic trauma and post-surgical neurological deterioration (Cudia and Duval, 1997). Most authors, while scoring postoperative results of spinal decompression in IVDD, do not quantify manipulation of the spinal cord during the procedure (Prata, 1981; Blight, 1991; Necas, 1999; Moissonnier et al., 2004; Hasegawa et al., 2007; Downes et al., 2009).

Trauma to the spinal cord caused by a weight impact (at a speed of $2 \mathrm{~m} / \mathrm{s}$ ) results in axonal degeneration. Furthermore, distortion of the diameter of the spinal cord is one of the main factors determining mechanical response to impact. Variations in dural elasticity, viscoelasticity of the parenchyma, and fluid pressure may be responsible for variation in tissue damage when diameter of the spinal cord is considered (Blight and Decrescito, 1986). Also, the greater the distance, weight, and time of injury to the spinal cord (at a same velocity), the greater the histological and neurological damage and the less chance the individual will have of recovering (Basso et al., 1996; Lee et al.,
2013). In healthy dogs, a study found no correlation between surgical manipulation of the spinal cord and postoperative neurological status. They used delicate instruments to touch the spinal cord and considered that it could provide mild trauma (Souza, 2010). Differently from Souza (2010), that studied extradural contacts in the spinal cord with no IVDD, we hypothesized that in the presence of endogenous pathophysiological events caused by IVD extrusion, manipulation of the spinal cord could lead to postoperative neurological deterioration.

The purpose of the present study was to investigate whether extradural contact to the spinal cord with surgical instruments during the approach to the vertebral canal of dogs with thoracolumbar IVD extrusion and extradural manipulation during removal of extruded disc material would result in neurological deterioration in the early and/or late postoperative period.

\section{MATERIALS AND METHODS}

This study was approved by our institutional Ethics Committee for the Use of Animals (CEUA, licence reference 035/2013; approved 2 February 2013). Nineteen dogs with thoracolumbar IVD extrusion were enrolled in this study, regardless of gender and age. A general clinical and neurological examination and imaging of the thoracolumbar region using radiography, myelography, or computed tomography (CT) with or without contrast were performed. Neurological assessment was quantified in the pre and postoperative periods using the scale developed by Olby et al. (2001). This scale has a system of five Stages and 14 Points, in which dogs classified as Stage (S) 1 Point (P) 0 have no pelvic limb movement and no deep pain sensation and those at Stage (S) 5 Point (P) 14 have normal pelvic limb gait. All dogs with scores between Stage 1 Point 1 and Stage 3 Point 8 were treated surgically.

Decompressive surgery via hemilaminectomy was performed on the side with the greatest amount of extruded disc material as observed via myelography and/or CT. Extruded disc material was removed using a $2 \mathrm{~mm}$ curette with soft lateral movements, below and/or above the dura mater of the affected area. Surgery was always performed by one of two main surgeons. Involuntary or unavoidable extradural contact 
during access to the vertebral canal and/or removal of disc material were recorded when they caused a deviation of the spinal cord or produced involuntary muscle contraction.

Neurologic exam and classification of the dogs was performed on initial presentation, immediately before surgery, 24 and 48 hours after surgery (early postoperative period), and 7 , $15,30,60$, and 90 days after surgery (late postoperative period). Position of the extrusions were also recorded for correlation with the number of extradural contacts.

Normality analysis was performed with the Shapiro-Wilk test. Non-parametric tests for paired data were used. Data are presented as median and interquartile range (IQR). Spearman's rank correlation coefficient (r) was computed to study the correlation between extradural contacts and neurological progression, as well as a possible correlation between neurological grade before surgery and neurological grade after surgery. The Wilcoxon signed-rank test was used when the neurological stage before surgery was different than the one after surgery. The Mann-Whitney $U$ test was performed to evaluate the influence of the position of the extruded material in extradural contacts. Kruskal-Wallis was used to study the effect of extradural contacts on time until recovery of motor function. Values in which $\mathrm{P}<0.05$ were considered to be significantly different. Statistical analyses were performed with SPSS 23.0 software.

\section{RESULTS}

Before decompressive surgery, 11/19 dogs (58\%) had paraplegia and 8/19 (42\%), paraparesis (ambulatory or nonambulatory). All dogs had deep pain sensation on the day of surgery. At the end of the study, $16 / 19(84 \%)$ had mild ataxia or normal ambulation, $1 / 19(5.3 \%)$ had paraplegia with nociception, $1 / 19(5.3 \%)$ paraplegia without nociception and $1 / 19 \quad(5.3 \%)$ with had paraparesis.

During surgery, there was extradural contact and manipulation during both access to the canal and removal of the extruded material in 16/19 dogs $(84 \%)$. Extradural contacts solely during removal of the extruded material were observed in $3 / 19$ dogs $(16 \%)$. Based on position of the extruded IVD material, there was significantly more extradural contacts in the group that had ventrolateral extrusions (Table 1).

There was no significant correlation between the number of extradural contacts observed during surgery and neurological stage at 24 and 48 hours, 7, 15, 30, 60 and 90 days after surgery (Table 2). In addition, the median number of extradural contacts did not significantly influence the time it took dogs to move their digits or pelvic limbs (without ambulation), to bear the weight, and to walk (Table 3).

Table 1. Number of dogs (\%) that underwent hemilaminectomy and extradural contacts, median (IQR), according to position within the vertebral canal of extruded intervertebral disc material

\begin{tabular}{cccc} 
& \multicolumn{2}{c}{ Position of extruded disc material } & \multirow{2}{*}{$P$ value } \\
\cline { 2 - 3 } & Lateral & Ventrolateral & - \\
Number of dogs & $15 / 19(79 \%)$ & $4 / 19(21 \%)$ & $<0.001$ \\
\hline Extradural contacts & $10(10)$ & $37.5^{*}(11.75)$ & \\
\hline \multicolumn{2}{l}{ The Mann-Whitney T test was used and the median (IQR) is presented. } & \\
${ }^{P} \mathrm{P}<0.05$ indicates a significant difference. &
\end{tabular}

Table 2. Spearman's correlation between extradural contacts during surgery for all 19 dogs and neurologic stage of each dog after surgery at 24 and 48 hours, $7,15,30,60$, and 90 days

\begin{tabular}{ccc}
\hline \multirow{2}{*}{ Different times after surgery } & \multicolumn{2}{c}{ Correlation between neurological stage after surgery } \\
& $r$ value & $P$ value \\
\cline { 2 - 3 } & $\mathrm{r}=-0.026 ;$ & $\mathrm{P}=0.917$ \\
and extradural contacts & $\mathrm{P}=0.290$ \\
7 days & $\mathrm{r}=-0.256 ;$ & $\mathrm{P}=0.193$ \\
15 days & $\mathrm{r}=-0.313 ;$ & $\mathrm{P}=0.130$ \\
30 days & $\mathrm{r}=-0.360 ;$ & $\mathrm{P}=0.093$ \\
60 days & $\mathrm{r}=-0.396 ;$ & $\mathrm{P}=0.216$ \\
90 days & $\mathrm{r}=-0.297 ;$ & \\
\hline
\end{tabular}


Table 3. Influence of extradural contacts observed during hemilaminectomy in 19 dogs with intervertebral disc extrusion on time until recovery of movement in digits or pelvic limbs (without ambulation), weightbearing, and ambulation. The number of $\operatorname{dogs}(n)$ in each group varied according to their neurological status before surgery

\begin{tabular}{ccc}
\hline Times until recovery of pelvic limb motor function & $\begin{array}{c}\text { Extradural contacts } \\
\text { Median (IQR) }\end{array}$ & $P$ value \\
\hline $\begin{array}{c}\text { Time until movement of digits or pelvic limbs (without } \\
\text { a } \\
\leq 7 \text { days }(n=7) \\
>7 \text { days }(n=3)\end{array}$ & $12.5(11.75)$ & $\mathrm{P}=0.360$ \\
\hline Time until weight-bearing $(n=14)$ & $13(20)$ & $\mathrm{P}=0.434$ \\
\hline$\leq 7$ days $(n=3)$ & $7(18)$ & $10(5)$ \\
\hline 7 days $(n=11)$ & & $\mathrm{P}=0.743$ \\
\hline Time until ambulation $(n=16)$ & $24(26.5)$ & \\
\hline & $12(10)$ & \\
\hline
\end{tabular}

Kruskal-Wallis was used and the median (IQR) is presented.

${ }^{*} \mathrm{P}<0.05$ indicates a significant difference.

There was no change in neurological grade between the day of surgery and the early postoperative period, at 24 and 48 hours (Wilcoxon test, $\mathrm{P}=0.414$ ). During this period, most dogs (13/19) maintained the same neurological grade they had before surgery, 4/19 dogs improved and $2 / 19$ deteriorated. At the seventh day after surgery, 13/19 dogs showed a neurological improvement (Table 4) and there was a significant difference (Wilcoxon test, $\mathrm{P}<0.05)$ compared with the neurological grade before surgery. Similarly, at 90 days, most dogs (17/19) improved their neurological status (Wilcoxon test, $\mathrm{P}<0.001$ ) when compared with the preoperative assessment. Neurological stage before surgery showed a significant correlation with neurological progression in all studied moments (Table 5).

\section{DISCUSSION}

Several papers report that, following surgical decompression, some dogs may have a satisfactory recovery, a full recovery, or irreversible sequelae (Moissonnier et al., 2004;
Kunz et al., 2015; Rohner et al., 2015). The use of intraoperative ultrasound can be helpful in decreasing manipulation of the cord and confirming removal of extruded disc material, but it may not be readily available (Bonelli et al., 2015). Residual disc material within the vertebral canal has been identified in many cases and can be considered responsible for lack of improvement or worsening after surgery (Van Goethem et al., 2002; Forterre et al., 2010; Stigen et al., 2010). A study in healthy dogs found that extradural contacts did not result in neurological changes in the early postoperative period (Souza, 2010). While our results are in accordance with findings in healthy dogs, they are contrary to our hypothesis that extradural manipulation in the presence of intervertebral disc disease would contribute to iatrogenic spinal cord injury. These findings suggest that there are no additional detriments related to a careful inspection of the vertebral canal for removal of as much extruded material as possible, as long as the surgeons are careful in manipulating the spinal cord. 
Consequences of intraoperative...

Table 4. Number of extradural contacts observed during hemilaminectomy in 19 dogs with intervertebral disc extrusion and their neurologic stage before surgery and after surgery at 24 and 48 hours, 7, 15, 30, 60, and 90 days. Neurologic stage was classified according to Olby et al. (2001)

\begin{tabular}{|c|c|c|c|c|c|c|c|c|}
\hline \multirow[t]{2}{*}{ Dog } & \multirow{2}{*}{$\begin{array}{c}\text { Number } \\
\text { of } \\
\text { contacts }\end{array}$} & \multicolumn{7}{|c|}{ Neurologic progression } \\
\hline & & $\begin{array}{l}\text { Before } \\
\text { surgery }\end{array}$ & $\begin{array}{c}24 \text { and } 48 \\
\text { hours }\end{array}$ & 7 days & 15 days & 30 days & 60 days & 90 days \\
\hline $\operatorname{Dog} 1$ & 7 & S1P2 & S1P2 & $\mathrm{S} 2 \mathrm{P} 4$ & S4P10 & S5P12 & S5P14 & S5P13 \\
\hline $\operatorname{Dog} 2$ & 8 & S1P2 & $\mathrm{S} 1 \mathrm{P} 2$ & S2P3 & $\mathrm{S} 2 \mathrm{P} 4$ & S4P11 & S5P13 & S5P13 \\
\hline Dog 3 & 12 & S1P2 & $\mathrm{S} 1 \mathrm{P} 2$ & $\mathrm{~S} 2 \mathrm{P} 4$ & S2P5 & S4P9 & S5P12 & S5P14 \\
\hline $\operatorname{Dog} 4$ & 6 & S3P6 & S3P6 & S4P6 & S5P12 & S5P14 & S5P14 & S5P14 \\
\hline $\operatorname{Dog} 5$ & 17 & S1P3 & S1P0 & $\mathrm{S} 2 \mathrm{P} 3$ & S2P5 & S4P10 & S5P14 & S5P14 \\
\hline $\operatorname{Dog} 6$ & 6 & $\mathrm{~S} 2 \mathrm{P} 3$ & $\mathrm{~S} 2 \mathrm{P} 4$ & S4P9 & S4P10 & S5P14 & S5P14 & S5P14 \\
\hline $\operatorname{Dog} 7$ & 7 & S2P3 & $\mathrm{S} 2 \mathrm{P} 4$ & S3P7 & S4P12 & S5P13 & S5P14 & S5P14 \\
\hline $\operatorname{Dog} 8$ & 3 & S1P2 & S1P2 & S2P5 & S4P10 & S5P13 & S5P14 & S5P14 \\
\hline Dog 9 & 13 & $\mathrm{~S} 1 \mathrm{P} 2$ & S1P2 & S2P3 & S2P5 & S4P10 & S5P12 & S5P14 \\
\hline Dog 10 & 41 & S3P7 & S3P7 & S4P9 & S4P11 & S5P14 & S5P14 & S5P14 \\
\hline Dog 11 & 8 & S2P3 & S2P3 & S2P4 & $\mathrm{S} 2 \mathrm{P} 4$ & S3P8 & S4P9 & S5P12 \\
\hline Dog 12 & 35 & S1P2 & S1P2 & S1P2 & S1P0 & S1P0 & S1P0 & S1P0 \\
\hline Dog 13 & 13 & S1P2 & S1P2 & S1P2 & S2P3 & S3P6 & S4P10 & S5P12 \\
\hline Dog 14 & 24 & S3P6 & S3P8 & S4P10 & S4P11 & S5P13 & S5P14 & S5P14 \\
\hline Dog 15 & 10 & S1P1 & S1P1 & S1P0 & S1P0 & S1P0 & S2P5 & S3P6 \\
\hline Dog 16 & 30 & S2P3 & S1P2 & S1P2 & S2P3 & S4P9 & S4P11 & S5P13 \\
\hline Dog 17 & 40 & $\mathrm{~S} 1 \mathrm{P} 2$ & S1P2 & S1P2 & S1P2 & S1P0 & S1P1 & S1P1 \\
\hline Dog 18 & 27 & $\mathrm{~S} 1 \mathrm{P} 2$ & $\mathrm{~S} 1 \mathrm{P} 2$ & $\mathrm{~S} 2 \mathrm{P} 4$ & S2P5 & S4P11 & S5P12 & S5P13 \\
\hline Dog 19 & 24 & S2P3 & S3P6 & S4P11 & S5P13 & S5P13 & S5P14 & S5P14 \\
\hline
\end{tabular}

Table 5. Spearman's correlation between neurological stage before hemilaminectomy in 19 dogs and their neurological stage after surgery at 24 and 48 hours, 7, 15, 30, 60 and 90 days

\begin{tabular}{ccc}
\hline \multirow{2}{*}{$\begin{array}{c}\text { Different times after } \\
\text { surgery }\end{array}$} & \multicolumn{2}{c}{$\begin{array}{c}\text { Correlation between neurologic stage before surgery with neurologic stage after } \\
\text { surgery }\end{array}$} \\
\cline { 2 - 3 } & R value & P value \\
\hline 24 and 48 hours & 0.766 & $<0001$ \\
7 days & 0.676 & 0.001 \\
15 days & 0.645 & 0.003 \\
30 days & 0.649 & 0.003 \\
60 days & 0.580 & 0.009 \\
90 days & 0.559 & 0.013 \\
\hline
\end{tabular}

Ventrolateral extruded disc material within the canal is reportedly the most difficult to remove (Moissonnier et al., 2004), which would result in greater manipulation of the spinal cord and thus account for the greater amount of contacts during our study. However, regardless of the number of extradural contacts most dogs had an unchanged neurological grade in the early postoperative period and improved seven days after surgery. Furthermore, at the end of this investigation, the improvement rate $(18 / 20)$ was in accordance with other authors (Ferreira et al., 2002; Ruddle et al., 2006; Bush et al., 2007), including one where corpectomies were performed, which allow minimal manipulation of the cord (Moissonnier et al., 2004).

Time until recovery of motor function in the present study was similar to those previously described by Trotter (1977), in which dogs with severe paresis and paraplegia usually started recovering voluntary motion of the pelvic limbs around 14-35 days; weight-bearing occurred around 14-42 days, and ambulation around 14-90 days. Coates (2000) reported a mean time for recovery of ambulation varying from 10 days in 
dogs which had only back pain or were paraparetic, to 51.5 days in those which were paraplegic. The authors of this study were unable to find any research that correlates neurological deterioration or delayed recovery and number of extradural contacts. The present study showed that number of extradural contacts seemingly did not influence time until recovery of movement in digits or pelvic limbs, weight-bearing, and ambulation.

Changes to microcirculation due to reperfusion (Hasegawa et al., 2007) and cord atrophy (Downes et al., 2009) have been associated with neurological deterioration. This type of secondary injury may have occurred in the dogs that showed a temporary or late deterioration after surgery. Furthermore, preoperative neurological status and owner's lack of compliance with postoperative recommendations may have contributed to deterioration in these cases. Another factor that could lead to neurological deterioration is duration of the extradural compression, where, in chronic cases, a hypervascularization surrounding the gray matter is related with secondary injury mechanisms in the spinal cord, possibly an inflammatory response, which do not depend on the primary mechanical injury, but are related to the loss of motor function and outcome (Blight, 1991). However, we did not use time of compression as a variable in this study since this depends entirely on the observation of the owners.

Various studies suggest that degree of neurological decline and presence or absence of nociception are determining factors in recovery of function in the pelvic limbs of dogs with thoracolumbar IVDD (Prata, 1981; Necas, 1999; Coates, 2000). Dogs with severely decreased or absent nociception in the pelvic limbs can regain ambulation, but they do not return to normal and neurological deficits may remain (Prata, 1981), thus preoperative neurological grade influences postoperative grade (Necas, 1999; Coates 2000; Laitinen and Puerto, 2005), also observed in the present study. A limitation of the present investigation was the lack of a control group and histological analysis of the spinal cords, which was not possible since the dogs were all clientowned and were still alive at the end of the study. The use of a control group was deemed unacceptable due to ethical reasons.

\section{CONCLUSIONS}

In most dogs, this study observed delicate extradural contacts during removal of the largest possible amount of extruded disc material. These did not result in postoperative neurological deterioration, given that most dogs remained unchanged after surgery, and later improved. Neurological progression in most of these patients correlated with the degree of preoperative neurological damage.

\section{ACKNOWLEDGMENT}

The main author received a scholarship from the Coordination for the Improvement of Higher Education Personnel (CAPES).

\section{REFERENCES}

BASSO, D.M.; BEATTIE, M.S.; BRESNAHAN, J.C. Graded histological and locomotor outcomes after spinal cord contusion using the NYU weight-drop device versus transection. Exp. Neurol., v.139, p.244256, 1996.

BLIGHT, A.R. Morphometric analysis of blood vessels in chronic experimental spinal cord injury: hypervascularity and recovery of function. J. Neurol. Sci., v.106, p.158-174, 1991

BLIGHT, A.R.; DECRESCITO, V. Morphometric analysis of experimental spinal cord injury in the cat: the relation of injury intensity to survival of myelinated axons. Neuroscience, v.19, p.321-341, 1986.

BONELLI, M.A.; TUDURY, E.A.; SANTOS, C.R.O. et al. Intraoperative ultrasonography of the vertebral canal in dogs. Arq. Bras. Med. Vet. Zootec, v.67, p.655-663, 2015.

BUSH, W.W.; TICHES, D.M.; KAMPRAD, C. et al. Functional outcome following hemilaminectomy without methylprednisolone sodium succinate for acute thoracolumbar disk disease in 51 nonambulatory dogs. J. Vet. Emerg. Crit. Care, v.17, p.72-76, 2007.

COATES, J.R. Intervertebral disk disease. Vet. Clin. N. Am. Small. Anim. Pract., v.30, p.77-110, 2000.

CUDIA, S.P.; DUVAL, J.M. Thoracolumbar intervertebral disk disease in large, nonchondrodystrophic dogs: a retrospective study. $J$. Am. Anim. Hosp. Assoc., v.33, p.456-460, 1997. 
DOWNES, C.J.; GEMMILL, T.J.; GIBBONS, S.E.; MCKEE, W.M. Hemilaminectomy and vertebral stabilisation for the treatment of thoracolumbar disc protrusion in 28 dogs. J. Small. Anim. Pract., v.50, p.525-535, 2009.

FERREIRA, A.J.; CORREIA, J.H.; JAGGY, A. Thoracolumbar disc disease in 71 paraplegic dogs: influence of rate of onset and duration of clinical signs on treatment results. J. Small. Anim. Pract., v.43, p.158-163, 2002.

FORTERRE, F.; GORGAS, D.; DICKOMEIT, M. et al. Incidence of spinal compressive lesions in chondrodystrophic dogs with abnormal recovery after hemilaminectomy for treatment of thoracolumbar disc disease: a prospective magnetic resonance imaging study. Vet. Surg., v.39, p.165-172, 2010.

HANSEN, H.J. A pathologic-anatomical study on disc degeneration in dog, with special reference to the socalled enchondrosis intervertebralis. Acta Orthop. Scand. Suppl., v.11, p.1-117, 1952.

HASEGAWA, K.; HOMMA, T.; CHIBA, Y. Upper extremity palsy following cervical decompression surgery results from a transient spinal cord lesion. Spine, v.32, p.197-202, 2007.

KRANENBURG, H.J.; GRINWIS, G.C.; BERGKNUT, N. Intervertebral disc disease in dogs part 2: comparison of clinical, magnetic resonance imaging, and histological findings in 74 surgically treated dogs. Vet. J., v.195, p.164-171, 2013.

KUNZ, R.E.; ROHRBACH, H.; GORGAS, D. et al. Assessment of intrathecal pressure in chondrodystrophic dogs with acute thoracolumbar disk disease. Vet. Surg., doi: 10.1111/vsu.12319, 2015.

LAITINEN, O.M.; PUERTO, D.A. Surgical decompression in dogs with thoracolumbar intervertebral disc disease and loss of deep pain perception: a retrospective study of 46 cases. Acta Vet. Scand., v.46, p.79-85, 2005.

LEE, J.H.; JONES, C.F.; OKON, E.B. A novel porcine model of traumatic thoracic spinal cord injury. J. Neurotrauma, v.30, p.142-159, 2013.

MOISSONNIER, P.; MEHEUST, P.; CAROZZO, C. Thoracolumbar lateral corpectomy for treatment of chronic disk herniation: technique description and use in 15 dogs. Vet. Surg., v.33, p.620-628, 2004.

NECAS, A. Clinical aspects of surgical treatment of thoracolumbar disc disease in dogs. A retrospective study of 300 cases. Acta Vet. Brno., v.68, p.121-130, 1999.
NOUSSITOU, F.L.; GORGAS, D.; ROHRBACH, H. et al. Assessment of intramedullary spinal pressure in small breed dogs with thoracolumbar disk extrusion undergoing hemilaminectomy. Vet. Surg., v.44, p.944948, 2015.

OLBY, N.J.; DE, R.L.; MUÑANA, K.R. et al. Development of a functional scoring system in dogs with acute spinal cord injuries. Am. J. Vet. Res., v.62, p.1624-1628, 2001.

PRATA, R.G. Neurosurgical treatment of thoracolumbar disks: the rationale and value of laminectomy with concomitant disk removal. J. Am. Anim. Hosp. Assoc., v.17, p.17-26, 1981.

ROHNER, D.; FORTERRE, S.; ROHRBACH, H. et $a l$. Influence of two types of self-retaining retractors on multifidus muscle blood flow during dorsolateral thoracolumbar hemilaminectomy in dogs. Vet. Comp. Orthop., v.28, p.256-262, 2015.

ROSENBLATT, A.J.; HILL, P.B.; DAVIES, S.E. et $a l$. Precision of spinal radiographs as a screening test for intervertebral disc calcification in Dachshunds. Prev. Vet. Med., v.122, p.164-173, 2015.

RUDDLE, T.L.; ALLEN, D.A.; SCHERTEL, E.R. $e t$ al. Outcome and prognostic factors in non-ambulatory Hansen Type I intervertebral disc extrusions: 308 cases. Vet. Comp. Orthop., v.19, p.29-34, 2006.

HARP, N.J.H.; WHEELER, S.J. Thoracolumbar disc disease. In: SHARP, N.J.H.; WHEELER, S.J. (Eds.). Small animal spinal disorders. Edinburgh: Elsevier Mosby, 2005. p.121-159.

SMOLDERS, L.A.; BERGKNUT, N.; GRINWIS, G.C. et al. Intervertebral disc degeneration in the dog. Part 2: chondrodystrophic and non-chondrodystrophic breeds. Vet. J., v.195, p.292-299, 2013.

SOUZA, G.S. Manipulação cirúrgica da medula espinhal em cães submetidos à hemilaminectomia toracolombar dorsolateral. 2010. 45f. Dissertação (Mestrado em Medicina Veterinária) - Escola de Veterinária, Universidade Federal de Santa Maria, Santa Maria.

STIGEN, O.; OTTESEN, N.; JADERLUND, K.H. Early recurrence of thoracolumbar intervertebral disc extrusion after surgical decompression: a report of three cases. Acta Vet. Scand., v.52, p.10, 2010.

TROTER, E.J. Canine Intervertebral disk disease. In: KIRK, R.W. (Ed.). Current Veterinary therapy VI small animal practice. Canada: Saunders, 1977. p.666673.

VAN GOETHEM, J.W.; PARIZEL, P.M.; JINKINS, J.R. Review article: MRI of the postoperative lumbar spine. Neuroradiology, v.44, p.723-739, 2002. 